\title{
Arsenic and trace metal mobility in alum shale areas in Sweden
}

\author{
G. Jacks ${ }^{1} \&$ P. Bhattacharya ${ }^{2}$ \\ ${ }^{1}$ Division of Water and Environmental Engineering, Department of Sustainable Development, \\ Environmental Science and Engineering, KTH Royal Institute of Technology, Stockholm, Sweden \\ ${ }^{2}$ KTH International Groundwater Arsenic Research Group, Department of Sustainable Development, \\ Environmental Science and Engineering, KTH Royal Institute of Technology, Stockholm, Sweden
}

\begin{abstract}
Alum shales found in Sweden are enriched in As and trace metals like Mo, Zn, Cd, Ni and U with the redox conditions being crucial for the mobilization of those elements. The shales have been mined, e.g. for uranium. Uranium is mobilized under oxidizing conditions, while arsenic is mobilized under reducing conditions. This plays a role under natural conditions in the alum shale but more so in the tailings after mining. An investigation of a natural area indicates small environmental risks while the utilization of the shales has left tailings that tend to leak into the environment.
\end{abstract}

\section{INTRODUCTION}

Black organic rich shales formed in deep sea environments under anoxic conditions are enriched in arsenic and a number of trace metals. Alum shales of Cambrian age are occurring in several sites in Sweden. They are present in southern Sweden and are outcropping in the eastern rim of the Caledonian mountains in northern Sweden. Similar shales are present in the British Isles and in North America in the Appalachian mountains. They have been used in generally minor projects for several purposes, extraction of alum for leather tanning, as fuel for production of lime mortar, for oil production (Sundin, 2008) and more recently to extract uranium. The mobilization of arsenic and the variety of trace metals are of concern under natural conditions, but many reports indicate that the tailings left after mining are of more serious concern. Several sites have been the subject to remediation with varying results. The experiences from this will be reviewed here as well as conditions in areas where no utilization has so far taken place. The main field work in this presentation has been done in an area in the Caledonian mountains where about $11 \%$ of the today globally known uranium occurrence is present.

This site is considered to be representative for areas where no mining has taken place while the literature survey is viewed upon as examples where the shale has been utilized.

\section{METHODS/EXPERIMENTAL}

Soils, plants, groundwater and surface water have been sampled. Water solutes were speciated by in-situ dialysis to reveal the forms in which trace elements were mobile. Water was analyzed by ICP-MS to get a large range of trace elements. The speciation was also done by the thermodynamic program Visual MINTEQ (Gustafsson, 2016).

A large number of publications are available from alum shale areas in southern Sweden which are illustrative for conditions where utilization of the shales has taken place.

\section{RESULTS AND DISCUSSION}

\subsection{The Viken area in the Caledonian mountains}

The soil in the area was not podzolised and had a neutral $\mathrm{pH}$ due to the Ordovician limestone surrounding the shale and mixed into the surface soil during the last Ice Age. The arsenic concentration in the soil profile down to $0.4 \mathrm{~m}$ was similar to the concentration in the parent material, the shale, indicating the arsenic was adsorbed onto ferric oxy-hydroxides at the site. The immobility of the arsenic in this site is supported by the low content in surface water and groundwater. The reason for this is likely to be the pronounced topography of the area that did not support any wetland formation where reducing conditions would exist. The lack of wetland means that there were no sinks for uranium. The concentrations of trace metals in soil indicate a substantial loss of $\mathrm{U}, \mathrm{Mo}, \mathrm{Zn}$ and Ni (Table 1) also verified by the elevated concentrations of notably $U$ and Mo in groundwater and surface water.

Uranium was noted taken up by plant while molybdenum was high especially in red clover, common fodder specie in the area. This could cause secondary copper deficiency which has been observed in alum 
Table 1. Metals and metalloids in shale, soil and crust.

\begin{tabular}{lcrrrrrr}
\hline Material & Mo & Cu & Zn & As & Ni & U & V \\
\hline Shale & 313 & 127 & 408 & 70 & 475 & 186 & 2133 \\
Soil & 139 & 58 & 201 & 65 & 103 & 27 & 480 \\
Soil* & 1.2 & 60 & 70 & 2 & 85 & 2.5 & 60 \\
\hline
\end{tabular}

* Global average as per Alloway (2015).

shale areas in southern Sweden (Frank 2004). Uranium in water was high, $>100 \mu \mathrm{g} \mathrm{L}^{-1}$, however in the form of calcium-carbonate-uranyl complexes, which are considered not to be toxic (Prat et al., 2009).

\subsection{Review of literature on alum shale sites in Southern Sweden}

The review of the literature regarding the environmental conditions in alum shale sites in southern Sweden indicates more of problems. At Ranstad in SW Sweden about 1.5 million tons of shale was mined and extracted for uranium. A recent review (SWAPO, 2005) shows that there is considerable pollution in receiving water courses of uranium. Arsenic in drainage water from the water filled open pit is low and arsenic is attached to ferric hydroxides and retained in the surface sediments (Widerlund \& Ingri, 1995). In surface water a sizeable transport of arsenic is possible only in water with an elevated content of DOC and ferric precipitates forming particulates or colloids (Jacks et al., 2013).

In another site on the island of Öland shale has been processed by burning (Lavergren et al., 2009). It has been observed that the in situ shale does not form acid drainage in response to weathering which is seen in the burnt shale. Considerable spread of metals are seen in connection to the burnt shale.

Arsenic and uranium in alum shale areas have been investigated in groundwater in dug and drilled wells (Jemander, 2008). Arsenic and uranium was in 30 wells below the respective health limits at $10 \mu \mathrm{g} \mathrm{L}^{-1}$ and $30 \mu \mathrm{g} \mathrm{L}^{-1}$. Only one well had $20 \mu \mathrm{g} \mathrm{L}^{-1}$ of U. Low concentrations of iron indicated that the well water was under oxidizing regime providing good adsorption of arsenic. Even though the alum shales have a high content of organic matter, in the order of $25 \%$, the organics are quite refractory and the formation of reducing conditions less common. The Caledonian shales have been subject to thermal alteration up to about $300^{\circ} \mathrm{C}$ (Snäll, 1988).

\section{CONCLUSIONS}

The investigation of the alum shale area in the Caledonian mountains shows that there is currently no environmental risks, possibly a risk for molybdenosis, secondary copper deficiency in animals. However, the use of concentrate supplemented with copper is likely to eliminate that risk. The uranium in groundwater and surface water is in a non-toxic form. The review of the report from sites, where the alum shale has been mined and utilized for different purposes, shows considerably more of problems. There are plans for large scale mining of the alum shale amounting to 700 million tons at the here investigated site. A considerable problem would be the tailings from the bacterial leaching of the shale, still containing $15-25 \%$ of the metals and the arsenic (Bhatti, 2015). If deposited so that the tailings are oxygenated, uranium and molybdenum will escape while a lowland deposition under reducing conditions would favor the escape of arsenic. Arsenic in surface water is in the boreal climate transported in particulate or colloidal form attached to ferric hydroxides and humic matter (Jacks et al., 2013). These forms of arsenic does not seem to be bioavailable.

\section{ACKNOWLEDGEMENTS}

The investigation of the Caledonian alum shale site was funded by the foundation ÅForsk, Stockholm in Sweden, which is thankfully acknowledged.

\section{REFERENCES}

Alloway, B. J. 2015. Heavy metals in soils. Mineral. Mag. 55(8): 1318-1324.

Bhatti, T. M. 2015. Bioleaching of organic carbon rich polymetallic black shale. Hydrometallurgy 157: 246-255.

Frank, A. 2004. A review of the "mysterious" disease in Swedish moose, related to molybdenosis and disturbances in copper metabolism. Biol. Trace Elem. Res. 102(1-3): 143-159.

Gustafsson, J.P. 2016. Visual MINTEQ ver. 3.1. URL: https://vminteq.lwr.kth.se.

Jacks, G., Slejkovec, Z., Mörth, M. \& Bhattacharya, P. 2013. Redox cycling of arsenic along the water pathways in a sulphidic metasediment area, N. Sweden. Appl. Geochem. 35: 35-43.

Jemander, L. 2008. Metals in an alum shale area in the county of Östergötland. M Sc thesis. Umeå Uinversity, Dept. of Natural Geopgraphy 32 pp.

Lavergren, U., Åström, M. E., Falk, H. \& Bergbäck, B. 2009. Metal dispersion in groundwater in an area with natural and processed black shale. Appl. Geochem. 24: 359-369.

Prat, O., Vercouter, T., Ansoborio, E., Fichet, P., Kurttio, P. \& Salonen, L. 2009. Uranium speciation in drinking water from drilled wells in southern Finland and its potential link to health effects. Environ. Sci. Technol. 43: 3941-3945.

Snäll, S. 1988. Mineralogy and maturity of alum shales of south-central Jämtland, Sweden. Swedish Geological Survey, Ser C 818. 46 pp.

Sundin, B. 2008. The Swedish shale-oil industry during the first half of the 19th century. Available at: www.divaportal.org/smash/get/diva2:274308.pdf.

SVAPO. 2005. Ranstad: Environmental and health risk assessment of the Tranebärssjön and tailings area. Report (In Swedish). 51 pp.

Widerlund, A. \& Ingri, J. 1995. Early diagenesis of arsenic in sediments of the Kalix estuary, northern Sweden. Chem. Geol. 125: 185-196. 


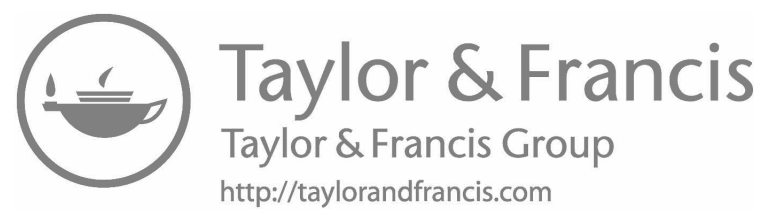


1.7 Arsenic in dust and road deposits 


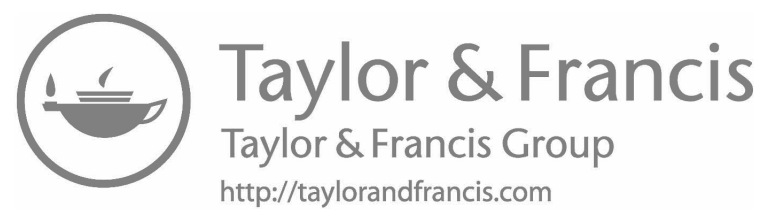

